\title{
APOPTOSIS, NUTRITION, AND METABOLISM OF TRANSPLANTED INTERVERTEBRAL DISC CELLS
}

\author{
APOPTOSE, NUTRIÇÃO E METABOLISMO DE CÉLULAS DE DISCOS INTERVERTEBRAIS \\ TRANSPLANTADAS
}

\section{APOPTOSIS, NUTRICIÓN Y METABOLISMO DE LAS CÉLULAS DE DISCOS INTERVERTE- BRALES TRASPLANTADAS}

\author{
Morgan B. Giers, ${ }^{1,2}$ Liudmila Bardonova, ${ }^{1,3,4}$ Kyle Eyster, $^{2}$ Vadim Byvaltsev, ${ }^{3,4}$ Mark C. Preul $^{1}$ \\ 1. St. Joseph's Hospital and Medical Center, Barrow Neurological Institute, Neurosurgery Division, Neurosurgery Research Laboratory, Phoenix, AZ, USA \\ 2. Arizona State University, School of Biological and Health Systems Engineering, Tempe, AZ, USA. \\ 3. Irkutsk Scientific Center of Surgery and Traumatology, Neurosurgery Research, Irkutsk, Russia \\ 4. Irkutsk State Medical University, Department of Neurosurgery, Irkutsk, Russia.
}

\begin{abstract}
Introduction: Apoptosis is a contributing factor to degenerating intervertebral disc (IVD). Disc regeneration has been attempted by transplanting cells into the disc, with some gains in disc height achieved in animal models. Here, we study whether the apoptotic microenvironment affects the transplanted disc cells. Methods: Human annulus fibrosus (AF) and nucleus pulposus (NP) cells were grown in media then starved for 5 days in vitro by not changing the media. Three aspects of apoptotic cell influence on the transplanted cells were tested in a total of 32 samples: 1) the effect of apoptotic cytokines in the media, 2) reduced glucose in the media, and 3) apoptotic cell bodies in the flask. The Trypan Blue, AlamarBlue ${ }^{\circledR}$, and 1,9-Dimethyl-Methylene Blue assays for sulfated glycosaminoglycan (sGAG) content were performed $(n=4)$. Results: There were significant decreases in cell viability between the control, $25 \%$ conditioned media $(C M)$ and starved control group. There were no significant differences in cell number, metabolic activity or sGAG production in cells grown in different conditioned media compared to cells grown in complete media. The cells of the control decreased in viability and number over the 5 days without feeding, then improved dramatically when feeding was resumed. Flasks that received transplanted cells in addition to renewed feeding did not recover as much as the cells in the re-fed group. Conclusions: Cytokines from starved cells negatively impact on the viability of healthy cells. Starving cells that receive new sources of nutrition have even higher viability than transplanted cells. This indicates that altering and improving the nutrient supply problem in the IVD could be a valuable option. Level of Evidence III; Case control study .
\end{abstract}

Keywords: Apoptosis; Intervertebral disc; Metabolism.

\section{RESUMO}

Introdução: A apoptose é um fator que contribui para a degeneração do disco intervertebral (DIV). A tentativa de regenerar o disco foi por meio de transplante de células no disco, com alguns ganhos de altura do disco alcançados em modelos animais. Aqui estudamos se o microambiente apoptótico afeta as células do disco transplantadas. Métodos: Células humanas do ânulo fibroso (AF) e do núcleo pulposo (NP) foram cultivadas in vitro em meio de cultura e privadas de nutrição por cinco dias, sem alteração dos meios. Três aspectos da influência de células apoptóticas em células transplantadas foram testados em um total de 32 amostras: 1) o efeito de citocinas apoptóticas no meio de cultura, 2) redução de glicose no meio e 3) corpos celulares apoptóticos no frasco. Realizaram-se ensaios com azul de tripano, AlamarBlue ${ }^{\circledR}$ e 1,9-dimetil azul de metileno para o teor de glicosaminoglicano sulfatado (sGAG) ( $\left.n=4\right)$. Resultados: Constataram-se decréscimos significativos na viabilidade celular entre o grupo controle, meio condicionado (MC) a 25\% e grupo controle privado de nutrição. Não houve diferenças significativas no número de células, atividade metabólica ou produção de sGAG em células cultivadas em diferentes meios condicionados em comparação com o meio completo. As células de controle tiveram redução de viabilidade e de número ao longo dos 5 dias sem alimentação; a seguir, houve melhorara substancial ao se retomar a alimentação. Os frascos que receberam células transplantadas, além da alimentação renovada, não se recuperaram tanto quanto as células do grupo realimentado. Conclusões: As citocinas de células famintas tiveram impacto negativo sobre a viabilidade das células saudáveis. As células famintas que recebem novas fontes de nutrição têm viabilidade ainda maior do que as células transplantadas. Isso indica que alterar e melhorar o fornecimento de nutrientes no DIV pode ser uma opção valiosa. Nível de Evidência III; Estudo de caso controleg.

Descritores: Apoptose; Disco intervertebral; Metabolismo.

\section{RESUMEN}

Introducción: La apoptosis es un factor que contribuye a la degeneración del disco intervertebral (D/V). El intento de regenerar el disco fue por medio de trasplante de células en el disco, con el que se ganó el aumento de altura del disco logrado en modelos animales. Aquí estudiamos si el microambiente apoptótico afecta a las células del disco trasplantadas. Métodos: Células humanas del anillo fibroso (AF) humano y del núcleo pulposo (NP) fueron cultivadas in vitro en medio de cultivo y privadas de nutrición por 5 días, sin alteración de los medios. Tres aspectos de la influencia de las células apoptóticas trasplantadas se probaron en un total de 32 muestras: 1) el efecto de las citoquinas apoptóticas en el medio de cultivo, 2) reducción de la glucosa en el medio y 3) los cuerpos celulares apoptóticos en el matraz. 
Se realizaron ensayos con azul de tripano, AlamarBlue ${ }^{\circledR}$ y 1,9-dimetil-azul de metileno para el contenido de glicosaminoglicano sulfatado (sGAG) $(n=4)$. Resultados: Se constataron disminuciones significativas de la viabilidad celular entre el grupo control, medio condicionado (MC) al $25 \%$ y el grupo control privado de nutrición. No hubo diferencias significativas en el número de células, la actividad metabólica o producción de sGAG en células cultivadas en diferentes medios condicionados en comparación con el medio completo. Las células de control tuvieron reducción de viabilidad y de número a lo largo de los 5 días sin alimentación; luego, hubo una mejora sustancial al reanudar la alimentación. Los matraces que recibieron células trasplantadas, además de la alimentación renovada, no se recuperaron tanto como las células del grupo alimentado nuevamente. Conclusiones: Las citoquinas de las células privadas de alimento tuvieron un impacto negativo en la viabilidad de las células sanas. Las células hambrientas que reciben nuevas fuentes de nutrición tienen mayor viabilidad que las células trasplantadas. Esto indica que cambiar y mejorar suministro de nutrientes en el DIV puede ser una opción valiosa. Nivel de Evidencia III; Estudio de caso controlg.

Descriptores: Apoptosis; Disco intervertebral; Metabolismo.

\section{INTRODUCTION}

Back pain effects $70 \%-85 \%$ of the population in developed nations during some point of their lives, and is a symptom of intervertebral disc (IVD) degeneration. ${ }^{1}$ The large population suffering from back pain results in significant economic costs due to lost productivity and health care expenses, estimated at $\$ 34$ billion $^{2}$ to the United States alone. Spinal degeneration, including IVD, can take many forms, complicating the understanding of the underlying degenerative mechanisms.

The IVD consists of three distinct anatomical segments: the endplate, the annulus fibrosus (AF), and the nucleus pulposus (NP). The endplate houses the capillaries that brings nutrients into the disc, and connects the rest of the disc with the adjacent vertebral body. The annulus fibrosus, made up of interconnected concentric lamellae, provides structural rigidity for the disc. The NP, a gelatinous structure, helps to evenly distribute compressive force across the disc.

Current treatment options for degenerative discs include conservative medical therapy, chronic pain therapy, transcutaneous minimally invasive disk procedures, and discectomy, whether alone or combined with a spinal fusion. ${ }^{3}$ While surgical treatment may resolve pain in the short term, mechanical differences in and around fused and healthy spine segments can lead to further degeneration in the adjacent segment discs. ${ }^{4}$ Due to mechanical degradation, patients may have to adjust their lifestyle to account for the reduced range of motion. While such restriction is especially difficult for younger patients, even older patients may be severely impacted, leading to loss of ability to walk.

Disc regeneration would be a beneficial treatment for young IVD degeneration patients, who suffer most from adjacent segment wear due to their longer life expectancy. Improving the health of the endogenous cells or introducing new healthy cells into the disc are two possible regeneration strategies. Gruber, ${ }^{5}$ in 1998, showed that a high percentage of cells within the IVD undergo apoptosis, with degenerated specimens containing $53.5 \%$ viable cells compared to $73.1 \%$ in healthy specimens. Therefore, regional interruption or termination of apoptosis are potential regeneration strategies for improving disc health. Another possible treatment may be to introduce healthy cells into the degenerated disc, either by direct injection or incorporation a tissue engineered construct such as a hydrogel. Peroglio et al. ${ }^{6}$ attempted to seed hydrogels with NP cells in order to regulate their extracellular matrix space. During the 7-day experiment, cell density decreased, raising concerns of long-term viability. ${ }^{7}$ Mechanical stresses on the spine also plays an intricate part in disc health, the results of which are often seen in laborers or people who work in occupations subject to constant and extreme loading. Heavy loads on the spinal column have been associated with apoptosis. ${ }^{8}$ In rats, a 0.4 MPa load applied for 3 days or $1.3 \mathrm{MPa}$ load applied for $1 / 3$ day resulted in significant cell death.

Finally, it has been determined that an imbalance of nutrients within the disc environment can cause apoptosis, and as a result, degeneration. Researchers have used diabetes as a model for apoptosis $^{9}$ in the IVD, as it has been shown that diabetic patients may experience higher rates of degeneration than non-diabetic individuals. ${ }^{10}$ This could be a direct result of the sensitivity of the cells to glucose levels.
One method of treating the degeneration currently under investigation is the introduction of healthy cells into the disc. Mesenchymal stem cells have been used extensively, as they can differentiate into the AF and NP cell types found in the disc. Sakai et al. ${ }^{11}$ transplanted mesenchymal stem cells (MSCs) into mature rabbits that were tagged with fluorescent proteins to track cell proliferation, and found significantly increased cell numbers at 48 weeks; however, there was no testing to detect how many of the cells were apoptotic or alive, or which originated as MSCs. In a canine animal model, Serigano et al. used TUNEL to quantify the percentage of dead MSCs transplanted. ${ }^{12}$ Transplanted cell death was dependent on the quantity of cells introduced to the disc during the 16 -week study. ${ }^{12}$ Most data is currently from animal IVD models. However, pilot studies are underway in humans in Japan and Spain, with promising initial results. ${ }^{13,14}$

We investigated whether apoptotic endogenous cells have any influence on introduced healthy, viable cells. This was done by testing multiple factors when applying live cells to a flask containing dead cells in one experiment. In another experimental group, we used multiple levels of cell conditioned media to then investigate the effect of released signaling markers on live healthy cells.

\section{METHODS}

\section{Human af and np cell source}

Healthy human annulus fibrosus cells (HAFCs) and human nucleus pulposus cells (HNPCs) were purchased from ScienCell Research Laboratories (Carlsbad, CA, USA), who collected the cells from 24-week fetal tissue. Cells were screened for mycoplasma and tested negative by the supplying company.

\section{Cell culture}

T-75 poly-D-lysine (Sigma Aldrich, St. Louis, MO, USA) coated culture flasks were prepared as directed by ScienCell. Briefly, 1.5 $\mu \mathrm{g} / \mathrm{mL}$ poly-D-lysine was added to each culture flask and incubated at $37^{\circ} \mathrm{C}$ for 1 hour. The flasks were then rinsed with sterile $1 \times$ PBS prior to storage.

Cells were thawed in a $37^{\circ} \mathrm{C}$ water bath and expanded for 5 days in 50\% Dulbecco's modified eagles medium (DMEM):50\% F12 (Life Technologies, Grand Island, NY, USA) media supplemented with 10\% fetal bovine serum (Life Technologies, Grand Island, NY, USA) and 1\% penicillin/streptomycin (Sigma Aldrich, St. Louis, MO), henceforth called control media. The cells were then passaged into their experimental groups. Each experimental group had a sample size of $4(n=4)$ for each cell type, HNPCs and HAFCs.

\section{Conditioned media experiment}

Live control cells were grown to confluence fed with control media every two days. (Table 1) The dead control group was not fed over the 5-day period. The media was collected and centrifuged at 200 RCF, and the supernatant was saved. A portion of collected supernatant from the dead control was used as conditioned media for the $12.5 \%$ and $25 \%$ conditioned media groups, where the media was changed every 2 days. 
Table 1. Experimental design for all groups.

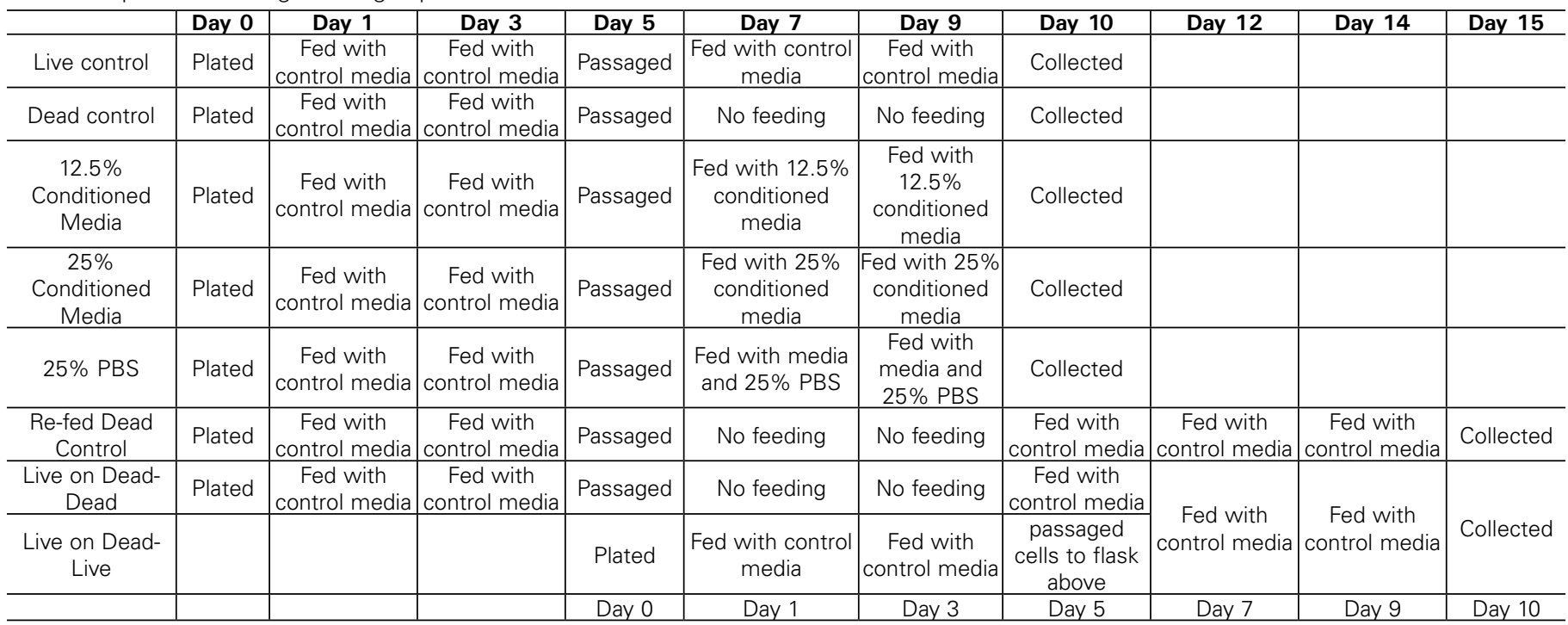

\section{5\% PBS experiment}

To determine the effect of decreased glucose in the CM group as opposed to the presence of apoptotic cytokines, one group was fed with 25\% PBS:75\% control media.

\section{Feeder layer experiment}

Following the steps from the negative control, cells were starved by not changing the culture media following passage. The media was taken off and stored, and new culture media, containing live cells or no cells, were introduced into the flask. The cells were then fed for 5 more days

\section{Cell viability and population density}

Cell viability was quantified following final collection of cells and media for analysis. The cells were centrifuged and then resuspended in 1x PBS. A sample of cells was taken and combined into a 1:1 solution of the PBS and Trypan Blue reagent (Life Technologies, Grand Island, NY, USA). The slides were then analyzed by a Countess II automatic cell counter (Life Technologies, Grand Island, NY, USA) and live/dead percentages, as well as cell densities, were obtained.

\section{Alamar blue assay}

Alamar Blue reagent (Life Technologies, Grand Island, NY, USA) was added to the cell culture flask containing media at a 1:10 ratio of AlamarBlue: media and incubated at $37^{\circ} \mathrm{C}$ for 2 hours. The media was then transferred to a 96 well plate. The absorbance was read at a wavelength of $570 \mathrm{~nm}$ with a reference wavelength of $600 \mathrm{~nm}$ on a Tecan Infinite 200Pro (Männedorf, Switzerland). The absorbance was normalized by cell count from the Trypan Blue cell viability test.

\section{Dimethylmethylene blue (DMMB) assay}

Sulfated glycosaminoglycan (GAG) content was assessed using a 1,9 dimethyl-methylene blue (DMMB) (Sigma-Aldrich, St. Louis, $\mathrm{MO})$ assay. Cells from the culture were centrifuged at $200 \mathrm{~g}$ for 4 minutes and resuspended in $1 \mathrm{x}$ phosphate buffered saline (SigmaAldrich, St. Louis, MO) before freezing at $-80^{\circ} \mathrm{C}$. Before testing, the cells were thawed and centrifuged. All but $0.5 \mathrm{~mL}$ of the supernatant was removed. The cells were resuspended in $1 \mathrm{~mL}$ of $50 \mu \mathrm{g} / \mathrm{mL}$ proteinase $\mathrm{K}$ (Roche, Branford, CT, USA) in 100mM Na2HPO4 adjusted to $\mathrm{pH} 8.0$ using $1 \mathrm{~N} \mathrm{HCl}$ (Fisher, Hampton, $\mathrm{NH}, \mathrm{USA}$ ). This solution was incubated at $37^{\circ} \mathrm{C}$ overnight to lyse the cells and then heated to $>90^{\circ} \mathrm{C}$ for 10 min to inactivate the proteinase K. $200 \mu \mathrm{L}$ of a DMMB reagent at $\mathrm{pH} 3$ was added to $20 \mu \mathrm{L}$ of each sample and absorbance read at $525 \mathrm{~nm}$ immediately. A standardized curve was prepared using bovine chondroitin-4-sulfate (Sigma-Aldrich, St. Louis, MO) for known concentrations between 0.125-1.0 $\mu \mathrm{g} / \mathrm{mL}$. Final concentrations were adjusted for resuspension volume and cell count from the Trypan Blue cell viability test.

\section{Statistical analysis}

Statistical analysis was performed using Statistica software. In all cases, the data were analyzed for normality using the half-normal probability plot. Statistical outliers were removed prior to ANOVA analysis. A main effects ANOVA was performed for all data in the conditioned media experiment and the 25\% PBS vs 25\% conditioned media experiment. A 2nd degree factorial ANOVA was used to assess significance between groups in the Feeder Layer Experiment. A post-hoc Fishers multiple comparisons test was used to assess significance between specific groups. The $p$ value for significance was set at $<0.05$ for all tests.

\section{RESULTS}

\section{Conditioned media}

Cell viability was highest in the cells grown in control media $(98.5 \% \pm 0.9 \%)$ (Figure $1 \mathrm{~A})$ and lowest in the dead control group $(58.6 \% \pm 13.2 \%)$. There were significant decreases in cell viability between the control group, the $25 \%$ conditioned media group $(p=0.002)$, and the dead control group $(p=0.000)$. There was no significant decrease in cell viability between the control group and the $12.5 \%$ conditioned media group $(p=0.77)$. Cell type, NP or AF, did not play a significant role in cell viability $(p=0.10)$. (Table 2$)$

The largest cell population was found in the flasks grown in the $12.5 \%$ conditioned media group $\left(1.1 \times 10^{5} \pm 6.0 \times 10^{4}\right)$ (Figure $\left.1 \mathrm{~B}\right)$ and the lowest was found in the dead control group $\left(7.1 \times 10^{4} \pm 5.8 \times 10^{4}\right)$; however, there were no statistically significant differences between levels of conditioned media $(p=0.42)$. The HNPCs $\left(1.1 \times 10^{5} \pm 5.4 \times 10^{4}\right)$ had a significantly larger population $(p=0.04)$ than the HAFCs $\left(7.2 \times 10^{4} \pm 3.3 \times 10^{4}\right)$.

Metabolic activity was not significantly dependent on conditioning level $(p=0.86)$ (Figure $2 A)$ or cell type $(p=0.75)$.

Sulfated GAG production (Figure 2B) was not significantly affected by the presence of conditioned media $(p=0.59)$ or cell type $(p=0.83)$.

\section{PBS vs conditioned media}

To determine the effect of apoptotic cytokine signaling in the media when compared to the loss of glucose and growth factors that was also present in the $25 \%$ conditioned media, media was prepared with $25 \%$ PBS. The $25 \%$ PBS group had higher cell viability $(97.5 \% \pm 1.3 \%)$ (Figure 1C) and cell population $\left(2.7 \times 10^{5} \pm 5.7 \times 10^{4}\right)$ (Figure 1D) than the 


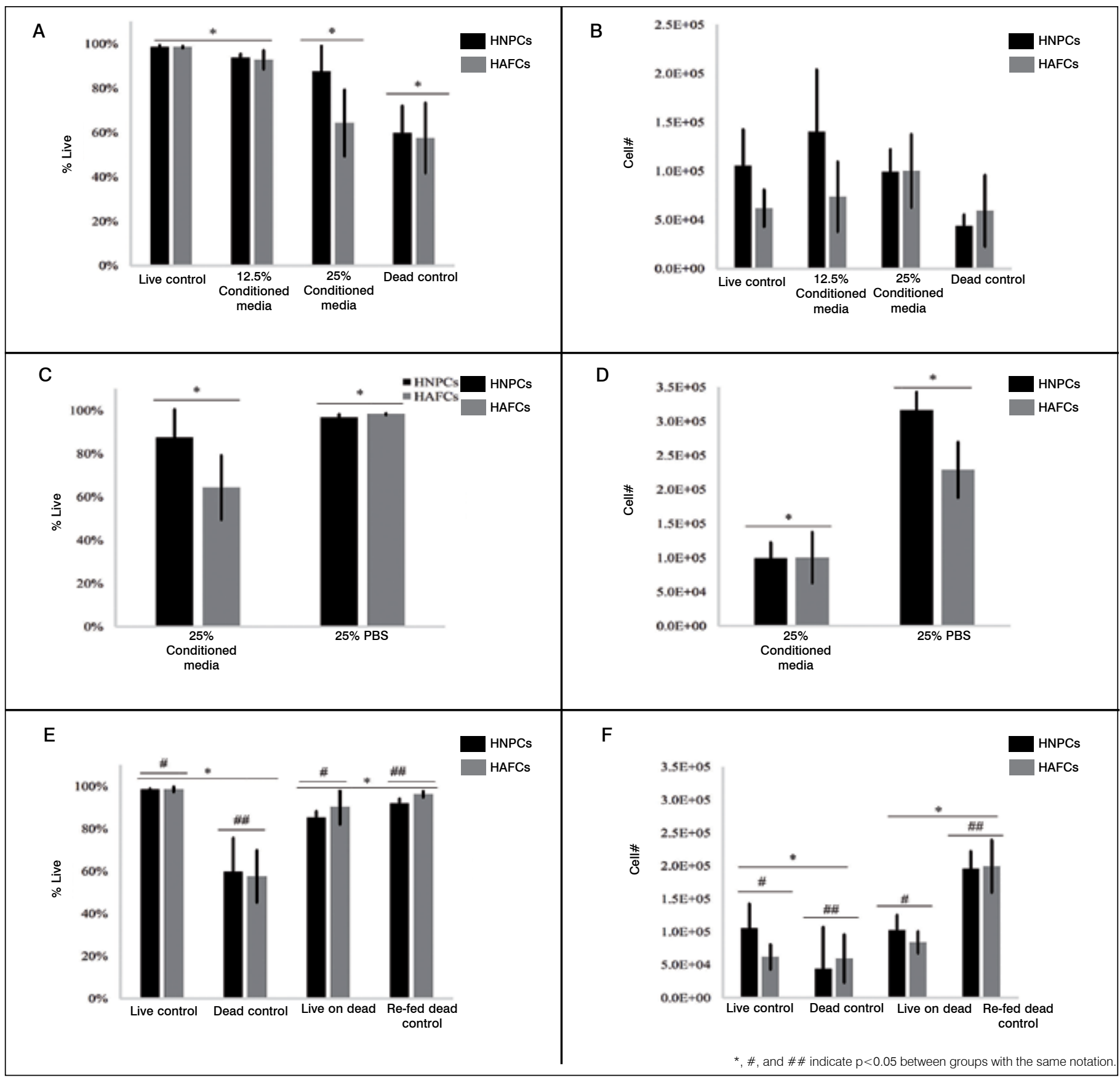

Figure 1. Cell viabilities and total number of cells for the A-B) condition media experiment, C-D) PBS control experiment, and E-F) and feeder layer experiment.

Table 2. Statistical significance (p) of independent variables on each dependent variable.

\begin{tabular}{c|c|c|c|c|c}
\hline & $\begin{array}{c}\text { Cell } \\
\text { type }\end{array}$ & $\begin{array}{c}\text { Conditioned } \\
\text { media level }\end{array}$ & $\begin{array}{c}\text { Pbs vs } \\
\text { conditioned } \\
\text { media }\end{array}$ & $\begin{array}{c}\text { Feeder } \\
\text { layer }\end{array}$ & $\begin{array}{c}\text { Feeder layer/ } \\
\text { conditioned } \\
\text { media } \\
\text { interaction }\end{array}$ \\
\hline Cell viability & 0.1 & $0.000^{*}$ & $0.003^{*}$ & $0.000^{*}$ & $0.000^{*}$ \\
\hline Cell population & $0.04^{*}$ & 0.42 & $0.000^{*}$ & $0.000^{*}$ & $0.000^{*}$ \\
\hline Cell activity & 0.75 & 0.86 & $0.000^{*}$ & 0.67 & $0.006^{*}$ \\
\hline $\begin{array}{c}\text { Sulfated GAG } \\
\text { production }\end{array}$ & 0.83 & 0.59 & $0.002^{*}$ & $0.03^{*}$ & $0.004^{*}$ \\
\hline
\end{tabular}

Statistically significant $(p<0.05)$.
$25 \%$ conditioned media group's cell viability $(75.9 \% \pm 18.0 \%, p=0.003)$ and cell population $\left(9.9 \times 10^{4} \pm 2.7 \times 10^{4}, p=0.000\right)$

Metabolic activity (Figure 2C) was higher in the $25 \%$ conditioned media group than the $25 \%$ PBS group $(p=0.000)$.

Sulfated GAG production (Figure 2D) was significantly lower $(p=0.002)$ in the $25 \%$ PBS group $\left(1.4 \times 10^{-7} \pm 3.8 \times 10^{-8} \mu \mathrm{g} / \mathrm{Cell}\right)$ than in the $25 \%$ conditioned media group $\left(5.3 \times 10^{-7} \pm 2.8 \times 10^{-7} \mu \mathrm{g} / \mathrm{Cell}\right)$.

\section{Feeder layer}

Healthy cells were added to a flask of dying cells and given control media to determine whether the presence of apoptotic cell bodies hindered or helped newly supplied cells. Additionally, cells were allowed to die and then given fresh media to determine the ability of the cell populations to recover. Using this system, cells were shown to decrease in viability (Figure 1E) and population (Figure 1F) from the control over the 5 days without feeding, then when cells were 


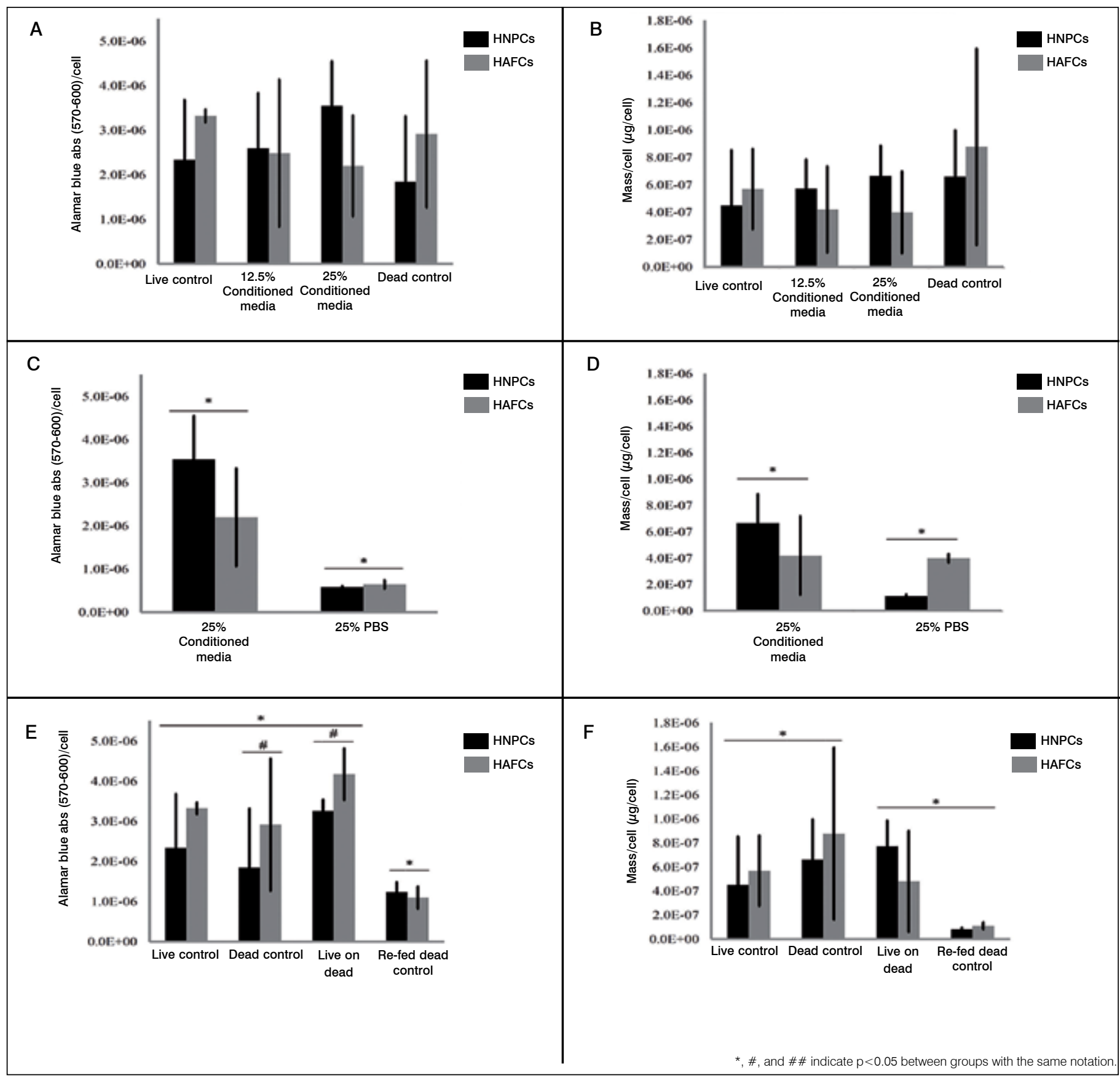

Figure 2. Cell metabolic activity and GAG production for the A-B) condition media experiment, C-D) PBS control experiment, and E-F) and feeder layer experiment.

fed for the following 5 days, their population and viability increased dramatically. In comparison, flasks that received new healthy cells in addition to 5 days of renewed feeding did not recover as much, in viability or population, as the cells in the re-fed only group.

Metabolic activity (Figure 2E) was significantly lower in the refed group than in the other 3 groups $(p=0.000)$ and was also significantly higher in the live-on dead group than in the dead control group $(p=0.01)$.

Sulfated GAG production (Figure 2F) was lowest in the re-fed dead control group $\left(9.4 \times 10^{-8} \pm 2.8 \times 10^{-8} \mu \mathrm{g} / \mathrm{Cell}\right)$ and highest in the dead control group $\left(7.5 \times 10^{-7} \pm 4.9 \times 10^{-7} \mu \mathrm{g} /\right.$ Cell).

\section{Discussion}

The conditioned media from apoptotic cells caused a decrease in cell viability of healthy disc cells. This effect was not due to a lack of growth factors and glucose, since the 25\% PBS group had higher viability than the 25\% CM group. Our data suggest that apoptotic cytokines in the media were responsible for decreased viability of the initially healthy cells. Adding live cells to a flask containing dead cells was shown to have significant effect on viability as well with the live on dead group having lower viability than the re-fed dead cells alone.

The metabolic rate of the cells also changed as a result of the environment. Adding the live, viable cells to a flask of dead cells increased the metabolic rates of the cells. Since fresh media was used, the increased metabolic rate was attributed to the apoptotic cells residing at the bottom of the coated flask, and not to the effect of the apoptotic cytokines that accumulated in the media over the 5 days.

Adherence of healthy cells introduced into the flask of dead cells did not appear to be hindered. There was no visual evidence of multiple cell layers, but the high final viability in the live on dead group suggests that dead cells either detached from the surface over time, or were pushed off the lysine flasks as healthy cells invaded the area. 
The dead cells would then have been discarded when the media was changed. In vivo IVD tissue, cellularity is only around $1 \%{ }^{15}$ and therefore attachment sites for new cells would not be problematic, even if dead cells were not immediately phagocytosed.

This study had several limitations. First, an in vitro model was chosen for this preliminary experiment to simplify the system and keep the experimental costs low, but it did remove complicating factors that could be important in vivo. Furthermore, this experiment was performed in 2D culture. Although all experiments were complete by passage iteration 4-5, it is possible that some of the cells could have undergone phenotypic changes toward a fibroblastic lineage. Furthermore, we did not perform any cell signaling analysis. From the low viability in the dead control group, we know some of the cells died, but we do not know the state of the remaining cells. For instance, were the surviving cells in both the CM group and the re-fed dead control group senescent, apoptotic, or unaffected? This will be the subject of future work, along with more extensive study of the apoptotic and chondrogenic signaling profiles of those cells.

It has been shown in previous research that evidence of apoptosis has been found in degenerated discs, and that mechanical strain and/ or poor transport of nutrients could be to blame for apoptosis and degeneration in human IVDs. The results of this study indicate that introducing live cells to an environment that has apoptotic cytokines can influence the health of the cells. This requires further exploration to determine the level of impact in an in vivo environment, and whether cell therapies could be successful in the long term, regardless of the negative microenvironment. It is also necessary to determine whether these therapies require adjunctive treatments to recover disc nutrition or removal of apoptotic cell debris and signaling factors. The results from the re-fed dead control group appear to indicate that the former might be a valuable treatment to explore, without the addition of transplanted cells. However, other aspects of the health of those re-fed cells would need to be investigated, such as possible senescence and phenotypic changes. Therapeutic developments may be amenable to local or regional spinal therapy strategies. Several teams have sought to address this critical nutrient transport deficit through mechanical and biological means such as spinal traction ${ }^{16-17}$ and enzymatic permeabilization ${ }^{18}$ respectively.

\section{CONCLUSIONS}

Cytokines from starved cells negatively impacted the viability of healthy cells. Starving cells that receive new sources of nutrition have even higher viability than transplanted cells. This indicates that treating the nutrient supply problem in the IVD could be a valuable treatment alone, without the need for further biological therapeutics.

\section{ACKNOWLEDGEMENTS}

This project was supported by funds from the Newsome Chair in Neurosurgery Research held by Dr. Preul, the Beverly and Millard Seldin Family, the Barrow Neurological Foundation, and the Russian Science Foundation (Project No. 15-15-30037).

All authors declare no potential conflict of interest related to this article.

CONTRIBUTION OF THE AUTHORS: Each author made significant individual contributions to this manuscript. MBG (0000-0002-2247-1167) ${ }^{\star}$, LB $(0000-0001-9340-5477)^{\star}, \mathrm{KE}(0000-0001-7749-2013)^{\star}$ were the main contributors in the drafting of the manuscript. MBG and LB evaluated the data of the statistical analysis. MBG, LB carried out the bibliographic research. MCP (0000-0001-8970-161X)*, VB (0000-0003-4349-7101)*, MBG revised the manuscript and contributed to the intellectual concept of the study. MCP and VB funded the study. ${ }^{*}$ ORCID (Open Researcher and Contributor ID).

\section{REFERENCES}

1. Andersson GBJ. Epidemiological features of chronic low-back pain. Lancet 1999;354(9178):581-5.

2. Gaskin DJ, Richard P. The economic costs of pain in the United States. J Pain 2012:13(8):715-24.

3. Byvaltsev VA, Kalinin AA, Belykh EG, Stepanov IA, Lazukov MV, Khachikyan AF, et al. Outcome analysis of direct lateral interbody fusion in the treatment of patients with degenerative disc diseases of lumbar spine. New Armenian medical journal. 2017;11(1):33-9.

4. Belykh E, Krutko AV, Baykov ES, Giers MB, Preul MC, Byvaltsev VA. Preoperative estimation of disc herniation recurrence after microdiscectomy: predictive value of a multivariate model based on radiographic parameters. Spine J. 2017;17(3):390-400.

5. Gruber HE, Hanley EN Jr. Analysis of aging and degeneration of the human intervertebral disc. Comparison of surgical specimens with normal controls. Spine (Phila Pa 1976). 1998:23(7):751-7.

6. Peroglio M, Grad S, Mortisen D, Sprecher CM, llien-Junger S, Alini M, et al. Injectable thermoreversible hyaluronan-based hydrogels for nucleus pulposus cell encapsulation. Eur Spine J. 2012;21(Suppl 6):S839-49.

7. Ding F, Shao ZW, Xiong LM. Cell death in intervertebral disc degeneration. Apoptosis. 2013;18(7):777-85.

8. Kuo YJ, Wu LC, Sun JS, Chen MH, Sun MG, Tsuang YH. Mechanical stress-induced apoptosis of nucleus pulposus cells: an in vitro and in vivo rat model. J Orthop Sci. 2014;19(2):313-22.

9. Jiang $L$, Zhang $X$, Zheng $X, R u A, N i X, W u Y$, et al. Apoptosis, senescence, and autophagy in rat nucleus pulposus cells:Implications for diabetic intervertebral disc degeneration. J Orthop Res. 2013;31(5):692-702.

10. Sakellaridis N. The influence of diabetes mellitus on lumbar intervertebral disk herniation.
Surg Neurol. 2006:66(2):152-4.

11. Sakai D, Mochida J, Iwashina T, Watanabe T, Nakai T, Ando K, Hotta T. Differentiation of mesenchymal stem cells transplanted to a rabbit degenerative disc model: potential and limitations for stem cell therapy in disc regeneration. Spine (Phila Pa 1976). 2005;30(21):2379-87.

12. Serigano K, Sakai D, Hiyama A, Tamura F, Tanaka M, Mochida J. Effect of cell number on mesenchymal stem cell transplantation in a canine disc degeneration model. J Orthop Res. 2010;28(10):1267-75.

13. Yoshikawa $T$, Ueda $Y$, Miyazaki $K$, Kozumi M, Takaura $Y$. Disc regneration therapy using marrow mesenchymal cell transplantation: a report of two case studies. Spine (Phila Pa 1976). 2010;35(11):E475-80

14. Orozco L, Soler R, Morera C, Alberca M, Sanchez A, Garcia-Sancho J. Intervertebral disc repair by autologous mesenchymal bone marrow cells: a pilot study. Transplantation. 2011;92(7):822-8.

15. Tanzil GS, Lemke M, Meier C, Ertel W, Kohl B, Huang Z, et al. Characterization of human anulus fibrosus and nucleus pulposus derived cells during monolayer expansion and in hydrogel cultures. BTRI. 2014;5:15-23.

16. Kuo YW, HsuYC, Chuang IT, Chao PH, Wang JL. Spinal traction promotes molecular transportation in a simulated degenerative intervertebral disc model. Spine (Phila Pa 1976). 2014;39(9):E550-6.

17. Giers MB, Munter BT, Eyter KJ, Ide GD, Newcomb AGUS, Lehrman JN, et al. Biomechanical and endplate effects on nutrient transport in the intervertebral disc. World Neurosurg. 2017;99:395-402.

18. Fields AJ, Ouyan A, Tang X, Lotz JC. Influence of cartilage endplate permeability on intervertebral disc nutrition. ORSTransactions. 2016;0308. 